\title{
8 Diaspora communities in transitional justice
}

\author{
A hidden presence
}

\author{
Stephan Parmentier, Mina Rauschenbach and \\ Laura Hein
}

\section{Introduction}

Although diaspora communities often play a vital role in transitional justice processes, a number of facets of their engagement remain under-explored in scholarly work. They have often been described either as conflict spoilers or peace-makers (Cochrane et al. 2009), but they are less often recognized as justice actors, victims and/or political agents. Their marginalized status is also observed in transitional and post-conflict settings where diasporas are often overlooked as "justice stakeholders" by their home countries, and perceived as being out of touch with the local realities and experiences due to their resettlement elsewhere (Haider 2014). In this sense, they are truly "forgotten actors" in transitional justice.

The very notion of "diaspora" possesses a long history and is most frequently associated with broad waves of migration, which can be motivated by a variety of reasons. In this chapter, we focus specifically on "conflict-generated" diaspora communities, which are fleeing their country of residence as a result of political violence and are seeking refuge in another country. In the Spanish-speaking world, the notion of "exiles" is preferred to capture this type of migration, thus highlighting the forceful nature of leaving a place for reasons of safety and security (Bolzman 2002; Teodora and Oprescu 2013) (on Argentina, see Jensen 2014; on Colombia, see Estrada et al. 2018; Martínez Leguízamo 2017). The notions of diaspora and exiles present many similarities such as the dispersal of the group(s) in several states, the (symbolic and material) connections to their home countries, the dream of returning, and the mobilization and organization of the group(s) to influence their home countries. Moreover, the work of memory and the recognition of their experiences give meaning to their presence abroad and grant them a legitimate (and sometimes constitutive) place as citizens and interlocutors in their country of origin (Bolzman 2002).

Particularly interesting for the scope of this chapter is that diasporas are recognized in their ability to develop an identity of their own, as well as an organizational project (Hovanessian, cited in Bolzman 2002). This refers to the capacity of the diaspora to transform forced migration into a "minority

DOI: $10.4324 / 9781003167280-11$ 
conscience", and to make themselves visible in the socio-political scene through their mobilization. In short, a diaspora is identified as such when it exists as a social actor (Bolzman 2002).

Scholarship has only begun to decipher the patterns, potential and challenges attached to diaspora engagement in transitional justice and is still very limited to sporadic analyses of their role in these processes. The involvement of diasporas in transitional justice is increasingly acknowledged from a double perspective (Wiebelhaus-Brahm 2016): first, as key justice stakeholders who can contribute to providing a comprehensive account of human rights violations committed in a country; and second, as direct victims of human rights violations back home and possessing the right to have their suffering acknowledged, akin to the citizens in their country of origin. Transitional justice scholars are progressively giving attention to diaspora activism and some studies have sketched the benefits attached to their engagement in transitional justice processes (Haider 2014; Young and Park 2009). Furthermore, in some cases important steps have been taken to incorporate diasporas in transitional justice measures (Bradley 2013; Haider 2014) in various ways: in providing input to transitional justice strategies (such as those in Haiti, Iraq, Kenya, Zimbabwe); in awareness-raising initiatives (e.g. Argentina, Armenia, Chile, Liberia and Sri Lanka); in the design and implementation of transitional justice measures (e.g. East Timor, Liberia, Sierra Leone); in supporting justice initiatives and providing evidence for these in their host country (i.e. Argentina, Cambodia, Chile, Rwanda, Syria); in truth commission processes (e.g. Colombia, Liberia).

Analysing all possible forms of diaspora engagement in transitional justice processes goes beyond the scope and objective of this chapter. Instead, we look at them with a particular focus on the role of turning points and transformative events in diaspora engagement, the types of transnational engagement observed in those communities, and the place of memory as a lynchpin of exiles' struggles for recognition.

The dimension of memory is particularly relevant to understanding the engagement of diaspora communities in transitional justice. Conflict-generated diasporas carry general memories of political violence and a troubled past, and specific memories of traumatic events and of loss (Lacroix and Fiddian-Qasmiyeh 2013). Memory practices can serve as symbolic forms of justice in that they are meant to acknowledge victims' experiences and suffering (Jimeno 2018; Rauschenbach et al. 2020). In addition, these memories shape diasporas' experiences, narratives and claims for justice in several ways. First, memories circulate and are transformed in interaction with the emergence and implementation of transitional justice processes. Moreover, these processes are often conceived and implemented in settings with contested understandings of a violent past (Jelin 2003; McEvoy and McGregor 2008), and this heterogeneity in historical representations can also be observed within diaspora communities. For example, in the case of Sri Lankan Tamils, the way in which the past may be understood (and its 
meaning for the present) can depend on factors such as different migration experiences, social and ethnic status, and the extent to which one identifies with the Tamil nationalist political project (Orjuela 2008; McDowell 2011; Étiemble 2017). Furthermore, the memories that drive diasporas' engagement in transitional justice processes are inevitably subjected to power relations, which may result in the marginalization of some experiences to the profit of other dominant accounts of the past. In the Tamil Sri Lankan diaspora, powerful and politicized subsections of these communities have engaged in the selective instrumentalization of particular narratives of the past aimed to legitimize their separatist and nationalist claims, resulting in the silencing of many other (individual and collective) narratives (Orjuela 2008).

Various factors can account for the heterogeneity and the relative salience of specific framings of the past in diasporas' relations to transitional justice at home. They include, first of all, diaspora migration experiences and organizational characteristics, and how these interact with the agendas and interests of their members (Orjuela 2008) and the political fields and opportunities of the home and host settings (Amarasingam 2015; Koinova and Karabegovic 2019). Moreover, these factors are linked to differences in access to broader international and transnational political fields and the actors occupying them, such as advocacy groups, the media, etc. (WiebelhausBrahm 2016). Finally, they are related to the legal and moral normative frameworks within which the discourse and practice of transitional justice are embedded (Orjuela 2018). Thus, depending on the context and time, diasporas may not have access to public and official spaces for the acknowledgement of their understandings of the past and institutions promoting them. In such cases, they are likely to resort to more informal and collective spaces of recognition such as digital platforms of exchanges or oral history projects (Karabegović 2014), private spaces (family events in the home) or personal modes of "mnemonic engagement" (e.g. family photography; oral histories) to uphold their memories within their collective consciousness (Halilovich 2014; Van Hear and Liberatore 2015).

We illustrate various forms of diaspora engagement with transitional justice processes through two examples from Latin America, namely the cases of Argentina and Colombia. These two case studies were chosen because of their relevance to factors highlighted as important in influencing the willingness and ability of diaspora communities to shape transitional justice politics in their home countries (e.g. Wiebelhaus-Brahm 2016). On the one hand, these factors include the socio-political characteristics of diaspora members and of the perpetrators of historic violence, the way in which some sort of political transition emerges (in a post-authoritarian context for Argentina and a peace process in a context of ongoing conflict for Colombia), and the world-historical time period in which transitional justice discussions take place (the birth of transitional justice in Argentina in a Cold War context, and the holistic view of transitional justice in Colombia as part 
of a contemporary globalized world order). On the other hand, both cases show similarities regarding the nature of the violence to be addressed (in both cases political violence), and the specific place of memory and its determining role in shaping and keeping the mobilization going, in providing meaning to a collective identification as an exile community and in bolstering the struggle for justice and truth.

\section{Two case studies of diaspora participation in transitional justice processes}

Exile from Argentina was the direct result of the political violence and repressive practices applied by the last military regime (1976-83) through its "anti-subversive struggle" against all (supposed) opponents. Recent studies estimate that up to 340,000 individuals were exiled during this period (Yankelevich 2007) with their main destinations being other countries in Latin America, Europe and the United States. Overall, the Argentine diaspora was composed of highly educated individuals and socio-political activists, which constituted the very reason for their persecution by the military regime (Wiebelhaus-Brahm 2016). Argentina is frequently considered a pioneer in dealing with human rights abuses during this particular period, because of its strong endeavours to implement a variety of political and legal strategies for the sake of justice and accountability. Since 1983, it has experienced a long and complex transitional justice process, consisting of several periods that have progressed in a non-linear fashion. The first period, during which the National Commission on the Disappearance of Persons (CONADEP) was established and the trials against the military junta were held, was followed by a long period of impunity and oblivion based on the impunity laws, and later by the still ongoing initiatives for truth and justice. Diaspora communities have been deeply involved in all phases of the transitional justice process in Argentina, but their precise roles have barely been explored.

Colombia, for its part, has been the theatre of more than 50 years of protracted and violent conflict involving multiple armed actors with various agendas (Díaz Pabón 2018). The conflict has affected populations from very diverse communities, different social classes and ethnic groups, who were located in different territorial spaces. Forced displacement, resulting in massive internal and international population movements, is one of the most prevalent human rights violations observed in this conflict. Overall, more than seven million Colombians have been forcibly displaced: at least six million have been internally displaced and more than one million have migrated out of Colombia due to the conflict but also because of inequality and lack of economic opportunities (Bermudez 2016; Swisspeace 2019). The recent peace process has provided the diaspora communities with unique opportunities to get involved in the transitional justice mechanisms and thus to become justice stakeholders, besides already being political actors. Following 
the peace accords of 2016, diaspora participation has been included in the mandate of three bodies established within the comprehensive justice framework: the Commission for the Clarification of Truth, Coexistence, and NonRepetition (hereafter TC), the Search Unit for Missing Persons and the Special Jurisdiction for Peace (hereafter JEP). Diaspora communities have been involved from the onset in the workings of the TC and the JEP. Yet there are many concerns about whether this inclusion will translate into effective participation (ICTJ 2018), particularly because of the lack of political will (Estrada et al. 2018). The TC's policy of inclusion of Colombian exiled voices is unprecedented in its scope, as it aims to account for the differentiated impacts of forced migration across the different social and ethnic groups represented in Colombia, and to collect pluralistic documentation of experiences across different host countries. These objectives are sought by organizing the international component of the TC in collaborative networks of nodes situated in various European, Northern American and Latin American countries.

\section{Different exiles' engagement and the role of turning points and "transformative events"}

Concerning Argentina, the general objectives of the exiles' activism, as well as their specific claims, clearly changed over time. Three partly overlapping phases of mobilization can be distinguished. They are closely related to socio-political transformations within the home country, as well as to the international and regional context that witnessed an increasing recognition of the legitimacy of human rights norms.

First, during the military junta period (1976-83) the aim of the exiles was mainly to denounce what was happening in Argentina and to put international pressure on the regime to halt the repression by means of collecting evidence and engaging in awareness-raising initiatives. A second phase of mobilization started with the end of the military regime and the transition to democracy. The Argentine exile communities reshaped their aims and gave support to several types of transitional justice mechanisms: the CONADEP truth commission established in 1984, and, simultaneously, the pursuit of the legal accountability of the Argentine perpetrators both in their own country as well as in that of their hosts. However, with the enactment of impunity laws (Ley de Punto Final 1986 and Ley de Obediencia Debida 1987), it became very clear that the Argentine state was no longer willing to prosecute those responsible. Disappointed by their home country, some exiles pursued cases in foreign courts based on the principles of universal jurisdiction and "passive personality" (with victims also possessing the nationality of the specific country), in countries such as Italy, France, Germany and Spain. During that period the primary goal was to put pressure on Argentina to open its domestic avenues for pursuing criminal justice. And indeed, the pressure caused by the criminal trials abroad was one of the key arguments 


\section{Stephan Parmentier, Mina Rauschenbach and Laura Hein}

brought into the parliamentary debates that preceded the annulment of the impunity laws in 2003. From the mid-1990s onwards, a third wave of exile activism arose from those who remained in the diaspora abroad, but even more so from those exiles who had returned to Argentina. They progressively mobilized for the acknowledgement of exile as a separate violation of human rights, their right to reparations, and the inclusion of their memories within the broader national narrative of the past, to voice their experiences and to be recognized as political actors in supporting the transitional justice process. Particularly in this phase, the Argentine exiles gradually emerged as justice stakeholders in Argentine society with very specific claims for the recognition of their own narratives and memories of the past, and of exile as a specific form of state repression.

An important transformative event for the mobilization of Argentine exiles was the arrest of former General Pinochet in London in 1998, which was particularly significant to sustain and legitimize the pursuit of the legal accountability of the Argentine perpetrators abroad. It energized the Argentine exiles, mostly in Europe, to pursue their search for accountability in their host countries (Roht-Arriaza 2005). Moreover, the confession in 1995 of former naval Captain Scilingo of his participation in the so-called death flights (vuelos de la muerte) strongly revitalized the Argentine public debate about the crimes committed by the junta. As a result, this "boom of memory" (Jensen 2014) in Argentine society sparked a new interest in the exiles' experiences, and in exile as a specific form of state repression.

The conflict in Colombia is a long-standing one, resulting in Colombians seeking political exile for the last 30 years, particularly during periods of peaking violence (Estrada et al. 2018). Yet before the onset of the peace process, only a minority of the diaspora was engaged in the denunciation of human rights violations and political activism in relation to the homeland (Bermudez 2016).

Granting participation possibilities to victims in the peace accords gave a special impetus for exiles, as historically overlooked justice stakeholders (Bedoya 2019), to claim their right to be included. The accords provided a particular momentum for Colombians living abroad to be recognized as justice stakeholders at the negotiation table and to be included in the development of the new political scenario that would follow (CNMH 2018; Martínez Leguízamo 2017). In addition to sending their inputs to the Havana process, diaspora members were included in victims' delegations in the third round of negotiations which allowed them to have their stories, as well as their justice and reparations needs, recognized in the Dialogue Agenda (Martínez Leguízamo 2017). The diaspora was also instrumental in placing the Colombian peace process and its relevance on the international agenda. Through numerous activities of lobbying and advocacy in their host countries, as well as the development of national and transnational networking initiatives (throughout Europe, South America and North America), the exiled have organized collectively and increased progressively their visibility as potential 
agents of change (Bermudez 2016; Martínez Leguízamo 2017; De Ryck and Lopez Villamil 2020). With their current participation in the different mechanisms developed within the comprehensive justice framework resulting from the peace accords, as well as the development of transnational networks of Colombian diasporas, the Colombia diaspora's engagement has thus been bolstered.

\section{Types of diaspora mobilizations}

One significant feature of the Argentinian exiles' activism, mainly in the late 1970s and early 1980s, was their engagement in transnational networking. They built networks between Argentine diaspora communities based in different countries and other diaspora communities (such as the Chilean ones), as well as alliances with international human rights organizations (such as Human Rights Watch and Amnesty International). This allowed the exiles to achieve international solidarity, and to appeal to the international community and public opinion to put pressure on the Argentine regime (e.g. Wiebelhaus-Brahm 2016; Franco and Pérez 2007). Alongside these more "horizontal forms of coordination" with civil society actors, the Argentine diaspora also engaged in "vertical coordination" with political actors in their host countries as well as with international political institutions such as the European Union (EU), the United States and also with the Vatican state. Despite being confined to certain sectors and only a fraction of the Argentine diaspora (Franco and Pérez 2007), several exiles' organizations were founded in Europe and Latin America. One particularly active exile organization was the Comisión Argentina de Derechos Humanos that had its major delegations in Paris, Mexico and Madrid, and intervened in the anti-junta fight mainly through its legal expertise. Indeed, another important characteristic of the Argentine diaspora mobilization of that period was that it accompanied humanitarian activism with a specific legal focus. In particular, the legal strategy explored the possibilities of legal protection under international human rights law and criminal prosecutions via international criminal jurisdictions. In this sense, from the very start, the exile communities went beyond the political and moral condemnation of serious human rights violations to walk the path of legal justice. Indeed, after the end of the military regime, the exiles played a crucial role in promoting the start of criminal trials in their host countries: as witnesses; by providing information and informal channels to access documents and testimonies; by giving logistical and financial support to witnesses travelling from Argentina; and by mobilizing public support (Roht-Arriaza 2005; Lutz and Sikkink 2001).

The founding document of the Argentine organization Hijas y Hijos del Exilio (2006) states:

Exile and its consequences were relegated as if it was a minor violation, unimportant; but many silences and omissions did not erase the 
wounds ... We need to tell our story and we want that the exile be treated as what it is: a violation of human rights.

(Translated from Spanish)

From the mid-1990s, former exiles founded their own organizations in Argentina (the Comisión de Ex-exiliados Argentinos por la Reparación CER - in 1998; the Comisión de Exiliados Políticos de la República Argentina - COEPRA - also in 1998; the Hijas y Hijos del Exilio in 2006) as well as abroad (Comisión de Exiliados Argentinos en Madrid - CEA-M - in 1999). Their objectives were primarily to obtain acknowledgement by the Argentine state that their exile was a consequence of forced displacement, and hence a human rights violation committed as part of the ideological depuration plan of the military junta, and the right to reparation deriving therefrom; to seek recognition of their role as political actors in denouncing the regime and in pursuing accountability; and to give voice to the exile experiences as part of an inclusive collective memory of the past. The national and international mobilization of exiles focused mainly on support for the draft law, the Reparación al Exilio (1998), which proposed a system of financial compensation for the exiles. Alongside very concrete claims (such as the recognition of titles and studies carried out abroad, and the acceptance of children of exiles as victims of the repression), the exiles' discourses drew attention to the symbolic and political aspects of the draft law: "our main claim is not monetary: we want a law that recognizes exile as a violation of human rights" (translated from Spanish. Pagina 12 2006; interview with Miguel Schclarek at COEPRA).

While the draft law was not approved, mostly because of the economic aspects, the judicial system from the late 1990s onwards started to accept reparation claims from exiles. Judges (up to the Supreme Court) began to recognize exile as a human rights violation, a deliberate practice of the military regime and, consequently, a harm that needed repairing.

In contrast, the Colombian diaspora cannot be described as a strong, widespread and organized movement overall, although it has become more visible and active in the transformation processes after signing of the peace accord. Private and individual forms of transnational engagement, particularly in relation to historical memory, have traditionally been more frequent than collective and public ones (Bermudez 2016). Only a minority of diaspora members were engaged in relation to the peace process, mostly individuals with a history of activism in Colombia and for whom such engagement was possible in the host society; either by their having a stable migrant status or such favourable economic circumstances that their engagement was not impeded by trauma. Moreover, diaspora engagement suffered from fragmentation within these migrant communities, related to gender, class, racial and regional divisions, which reflect the same cleavages existing in Colombia (Bermudez 2016). Divides also related to political identities, and what they imply in terms of expectations in relation to the peace process, with some diaspora members more likely to 
claim victim status, while others reject this status to the benefit of political agency (Dosdad and Louidor 2018). Colombian exiles have generally not benefited much from support from the Colombian state or its institutions, but their mobilization has significantly grown over the past 20 years due to the existence of effective opportunities in host societies. The Colombian state also reached out to the diaspora communities via the Ministry of Foreign Affairs and the National Centre for Historical Memory.

While the Colombian state has provided only limited support for diaspora engagement, political opportunity structures in certain host countries, particularly since the onset of the peace process, have facilitated its development into an organized movement, through possibilities for networking, advocacy as well as lobbying with local political leaders and institutions. Their mobilization has involved both horizontal coordination (i.e. relationships with civil society actors), and vertical coordination (i.e. relationships with host country policymakers and international organizations) (Stokke and Wiebelhaus-Brahm 2019). For example, Colombian exiles' organizations have developed significant transnational networks in Spain and the United Kingdom, involving government bodies, trade unions, non-governmental organizations, and human rights and academic institutions. Some of these organizations are also part of a broader transnational network of organizations, called the Oficina Internacional de los Derechos Humanos Acción Colombia (International Bureau for Human Rights Action on Colombia), involved in political advocacy with European institutions, states and the United Nations (UN), in relation to human rights issues in Colombia. These transnational activities, of raising public awareness and lobbying politicians, have helped to sustain the Colombian diaspora's engagement, as well as to strengthen European and international support for the peace process. While they are generally considered to offer less capacity to exiles to mobilize compared to organizations in Europe, national organizations based in various Latin American countries, including Mexico, Costa Rica, Chile, Argentina or Peru, have also been developed to support the struggle for the visibility of the victimization of Colombian exiles. Transnational networks, such as Revicpaz-LAC (Network of Colombian Victims for Peace in Latin American and the Caribbean) which were built on the legacy of regional exile experiences are also very active in supporting advocacy for Colombian exiles' visibility as justice stakeholders.

Informal civil society-led truth-seeking initiatives developed outside of Colombia also had a significant role in contributing to the active inclusion of diaspora perspectives in the peace process. An example is the Truth, Memory, and Reconciliation Commission of Colombian Women in the Diaspora, which was created in 2014 and has hubs in London, Barcelona, Brussels and Stockholm. Through the adoption of an active memory and empowerment approach, this Commission aims to highlight and document the role of women in exile and their specific and often marginalized experiences. Another initiative is the Foro Internacional de Victimas (International 
Victims Forum) created in 2014 which is a transnational network with coordinators in 18 cities across the world and which organizes events aimed at diaspora engagement in the peace process. It serves as a platform for communication, organization and participative action aimed at increasing the visibility of victims of the conflict abroad and at promoting their participation in the peace process.

\section{Memory as a lynchpin of exiles' struggles for recognition}

In Argentina, during the early years of the transition to democracy, exile experiences were marginalized in relation to other experiences of repression (Jensen 2014). The reasons for this marginalization were manifold. Public opinion was still influenced by the stigmatizing discourses of the junta against the exiles (accusing them of conducting an anti-Argentina campaign abroad), as well as by the prejudice of a "golden exile". Furthermore, the experiences of exiles were conditioned by a hierarchical logic of victims that compared the degree of suffering or damage of the exiles with respect to prison, death or disappearance (Jensen 2014). The exiles' sense of guilt, that they were "privileged among the victims", led them to stay silent about their experiences and consequently facilitated the marginalization of the exiles in the general discourses and memories about the repression.

Since the mid-1990s, however, there has been an increasing repositioning of exiles in memories of the repression alongside a boom of memory in Argentinian society. A new social interest in the exile emerged that helped to re-signify it as another repressive practice of the junta. Initially, such interest was expressed mainly in the publication of literature (biographies, life stories, interviews) and public debates that emphasized the individual and human dimension of the exiles' experiences. As exiles started to obtain a place in memories of the repression, groups of exiles mobilized further for the public acknowledgement of the political and collective dimension of the exiles' experiences, i.e. for the recognition of forced displacement as part of a planned cultural repression by the junta, thus placing the exiles among the victims of its ideological depuration. While the judicial recognition of reparations to exiles as victims of human rights violations was a first important step, it also remained an incomplete solution for the exiles since it limited the debate around reparations to its strictly material dimension. Furthermore, it led the exiles to search for individual judicial solutions, which again undermined the recognition of the collective dimension of exile, as well as the official and political acknowledgement of exiles' experiences. This lack of recognition of the political and collective dimension is the reason why exiles speak about "memorias lights", or "memorias anestesiadas" ("anesthetised memories"), when referring to the place of their experiences in Argentine society (Jensen 2014).

Within the context of the ongoing conflict in Colombia, "memory is an expression of rebellion against violence and impunity" (Schultz-Kraft 2017) 
and recovering the historical memory of the conflict is understood as a central, forward-looking process for victims to claim justice and reparation (Tamayo Gomez 2019). Within this broader process of collective memorymaking, Colombians who were forced to migrate have struggled, sometimes for decades, to have their exile recognized as an injustice resulting from the armed conflict. This struggle for visibility is complicated by official denial or by the perception of Colombia as a democratic state affected by an armed conflict, rather than as dictatorship like many other cases of exile in Latin America (Estrada et al. 2018). Within this context, individual and collective commemorative practices have acted as channels of recognition through which exiles have been able to keep their memories alive and continue their struggle for justice and reparation (Bermudez 2011; CNMH 2018). This was particularly important for exiles in the face of the invisibility of their victimhood back home until it was officially recognized in the peace agreements of 2016.

A noteworthy initiative which has helped to disseminate exiles' experiences within Colombia is the creation by the Centro Nacional de Memoria Histórica (CNMH - National Centre for Historical Memory) of a virtual space for Las voces del exilio (the Voices from Exile). This initiative was followed by a report aimed at "recognizing exile as a form of violence that has transversally affected the lives of individuals, groups and communities in exile around the world, as well as those who have returned to the country voluntarily or forcibly" (CNMH 2018, 17). This report describes also how remembrance practices aimed at preserving identity through language, food and other traditional practices, serve as forms of resistance against the uprooting that the exiled have suffered and as guarantees of non-repetition of past injustices (CNMH 2018). Moreover, informal initiatives such as the Truth, Memory, and Reconciliation Commission of Colombian Women in the Diaspora have focused specifically on the active promotion of women's perspectives in the reconstruction of historical memory, with the objective to break the double invisibility of exiled women (Bermudez 2016). More recently, Colombia's Truth and Reconciliation Commission (TRC), which began its mandate in late November 2018, has been working actively with exiles to collect their testimonies, individually and collectively, in order to recognize and give visibility to the role and impact of exile in Colombia's conflict. This truth-telling mechanism, for the very first time, gives exiles a voice. As Dr Carlos Beristain, a member of the TRC explained at a seminar in Brussels in October 2019, "[t]here is a truth about Colombia outside the country and we need to voice it". This TRC employs not only methodologies of testimony gathering, but also artistic practices to facilitate the expression of exiles' experiences and to promote their inclusion in the construction of the memory of the conflict in a participatory and healing manner. While the Colombian TRC displays much promise in its objectives and in its pioneering active inclusion of exiles, there are concerns about what it will be able to achieve, given its very short mandate (which was scheduled to end in 2021), 
and the unfavourable Colombian political context (Bermùdez Liévano 2020). The challenge given this polarized home context is to ensure that historically marginalized voices are included meaningfully and to have them acknowledged by the Colombian state.

\section{Discussion: lessons learnt from Argentina and Colombia}

These two prominent case studies can produce several interesting insights into the central theme of our chapter, namely to better understand the engagement of diaspora communities with transitional justice, with a particular focus on memory.

Both cases amply demonstrate the important contribution of diaspora communities to transitional justice, both in the host and the home countries. In the case of Argentina, during the military junta the aim of the exiles was mainly to increase international pressure on the regime to halt the ongoing repression. After the fall of the dictatorship, the exiles oriented their activities to ascertain the legal accountability of the Argentine perpetrators in their home settings and host countries (Sikkink 2012). From the mid-1990s, the exiles progressively mobilized for the acknowledgement of exile as a violation of human rights and the inclusion of their memories within the broader national narrative of the past. During this particular phase they emerged as specific justice stakeholders claiming the acknowledgement of their own narratives as a transnational community with shared experiences of exile. In the Colombian case, the exiles were truly forgotten actors and memory served as a key form of symbolic reparation until the final stages of the peace accords in 2016, when they suddenly emerged as justice stakeholders. With the increasing inclusion of victims within the transitional justice process, the struggle for the acknowledgement of the exiles' memories shifted from a more personal form to a more collective and organized one, as illustrated by initiatives such as the Voices from Exile and the Truth, Memory, and Reconciliation Commission of Colombian Women in the Diaspora. These collective initiatives and the late involvement of exiles in the peace accords made it impossible for the Colombian state to continue to overlook the voices of the exiles in the upcoming post-agreement justice process.

The differences in both cases are perfectly logical, as they reflect different approaches to transitional justice and different contexts. In the case of Argentina, the exile communities strongly focused on criminal accountability as the central form of transitional justice, while in the Colombian case the time was ripe for a more holistic approach, which also included elements of restorative justice and victim reparations. Moreover, the transitional justice dynamics were quite different. In the case of Argentina, most strategies and actions of transitional justice came from within the country and built on the work of the existing institutions of justice and memory. In contrast, Colombia shows the prominent role of the international community (such as the $\mathrm{UN}$ and the EU) in shaping the transitional justice process and its activities. 
This was partly due to the rapid development since 1995 of transitional justice as a broad and global field of research, policymaking and practice. Furthermore, the Colombian exiles were less organized in their mobilization efforts, mostly due to their heterogeneity, as opposed to the Argentinian exiles who were more homogenous and proactive.

Despite the many differences, several similarities also emerge from these brief case overviews. Both cases illustrate the importance of diaspora communities being actively involved in transitional justice institutions and arrangements, in order to raise awareness, provide evidence, push for truth and justice and, let us not to forget, also advocate for reparations for the victims of serious human rights violations, including their own victimization as exiles. Moreover, in both cases, the diasporas evolved from forgotten actors to justice stakeholders by means of a struggle for remembrance. From this perspective, they can easily be seen as stakeholders who shaped and transformed their victimhood into political and legal action, both in the host setting and the home country. Finally, both cases illustrate the non-linear shape of historical evolutions, which unfold as waves and cycles that come with ups and downs, as well as the importance of "turning points" and "transformative events" (Koinova 2018). In Colombia, it was definitely the peace process and the resulting accords, while in Argentina it was the combination of the Pinochet effect and the memory boom.

The two cases also provide ample evidence to explore theoretical frameworks concerning the engagement of diaspora communities with transitional justice. In terms of the benefits for transitional justice processes to engage with diaspora communities, both cases clearly illustrate the relevance of Wiebelhaus-Brahms' (2016) framework. Including the experiences of the Argentine and Colombian diaspora communities in truth and justice institutions has produced a fuller account of past human rights violations. Moreover, both diaspora communities clearly pushed for truth and justice for the violations committed against them, including exile as such, and for having their own suffering acknowledged and compensated. Finally, while it seems that individuals engaged in the Argentine and Colombian diasporas also acquired a greater stake in contributing to their countries' futures, this aspect must be the subject of further studies.

In recent years, a wide range of scholarship has contributed to a better understanding of diasporas' engagement with transitional justice institutions and procedures (see also Koinova and Karabegovic 2019). Several aspects find a clear connection with the experiences and working methods of the Argentine and Colombian diaspora communities. First, both communities (but particularly the Argentine diaspora) have successfully made use of "strategic framing" (Adamson 2013), by presenting external displacement as a specific type of human rights violations, and thus insisting on the notion of exiles rather than diaspora. Second, both communities can be seen to have acted as "brokers" (Adamson 2013) between different sectors of society involved in various ways in human rights, justice and peace. More 
specifically, both exile communities were very active in "coordination activities" (Karabegovic 2019), first by forming links with other diaspora communities and groups of human rights activists, and second by undertaking strong lobbying with policymakers, the media, etc. through institutional channels in their host countries and regions (such as the EU). Finally, both cases also clearly illustrate the "boomerang effect" (Keck and Sikkink 1998), whereby the diaspora communities solicited transnational and international actors in order to pressurize their home states to cease committing human rights violations and, later on, to step up transitional justice efforts to deal with past human rights violations.

\section{Conclusion}

In this chapter, we have focused on the role of diaspora communities as transnational actors in various transitional justice processes in two geographical settings: first, in relation to their home countries, which they have left behind (and often wish to return to); and second, in relation to their new host countries. From the limited examples available, it is clear that, overall, diaspora communities thus far are forgotten actors in transitional justice processes. Yet they often play an important role in raising awareness about human rights violations in their home state, in providing evidence and support to transitional justice institutions, and in advocating institutions that seek for truth, justice and/or reparations. In this line, diaspora communities have emerged in various settings as justice stakeholders in the domestic and international spheres. The role of remembrance in these endeavours is crucial, both at the individual level and the more collective one, as a symbolic form of transitional justice, especially when there is not (yet) a space for further forms of transitional justice. Although diaspora communities occupy a very specific position in between these different worlds, their presence frequently tends to remain hidden until specific turning points and transformative events enable them to become more visible.

While concise, the two case discussions of Argentina and Colombia have provided more elements to understand the particular backgrounds, working methods and objectives that diaspora communities draw upon. While postdictatorship Argentina constitutes a classical example in the field of transitional justice, with a clear focus on the criminal accountability of perpetrators, Colombia is a more recent case, displaying a holistic and innovative approach to dealing with past abuses. Both cases also illustrate the importance of expanding in-depth empirical case studies in order to broaden theoretical frameworks.

Finally, the experiences of Argentina and Colombia open the door for more research on more recent ongoing violent conflicts such as those in Afghanistan, Syria or Myanmar. These conflicts produce yet more exiles on a daily basis as well as new conflict-generated diaspora communities, whose very essence lies in their forced displacement to other countries and regions of the world. 


\section{References}

Adamson, Fiona. "Mechanisms of diaspora mobilization and the transnationalization of civil war". Transnational dynamics of civil war, edited by Jeffrey Checkel, Cambridge, Cambridge University Press, 2013, pp. 63-88, doi:10.1017/ CBO9781139179089.

Amarasingam, Amarnath. Pain, pride and politics: Social movement activism and the Sri Lankan Tamil diaspora in Canada. Athens, University of Georgia Press, 2015.

Bauböck, Faist T., editor. "Diaspora and transnationalism: Concepts, theories and methods". IMISCOE research, Amsterdam, Amsterdam University Press, 2010, https://cadmus.eui.eu/bitstream/handle/1814/14318/Diaspora_and_Transnationalis m.pdf. Accessed 12 February 2021.

Bedoya, Nicolas. As violence continues at home, exiled Colombians reconstruct collective memory. 2019, https://atindispatch.com/2019/04/18/as-violence-continues-a t-home-exiled-colombians-reconstruct-collective-memory. Accessed 14 December 2020.

Bermudez, Anastasia. "The 'diaspora politics' of Colombian migrants in the UK and Spain”. International Migration, vol. 49, no. 3, 2011, pp. 125-143, doi:10.1111/ j.1468-2435.2011.00689.x.

Bermudez, Anastasia. International migration, transnational politics and conflict: The gendered experiences of Colombian migrants in Europe. London, Palgrave Macmillan, 2016, doi:10.1057/978-1-137-53197-1.

Bermùdez Liévano, Andrés. Political tussle over truth and memory and Colombia. 2020, www.justiceinfo.net/en/truth-commissions/44027-political-tussle-over-truth-a nd-memory-in-colombia.html. Accessed 14 December 2020.

Bolzman, Claudio. "De l'exil à la diaspora: L'exemple de la migration chilienne", Autrepart, 2002, vol. 2, no. 22, pp. 91-107, www.cairn.info/revue-autrepa rt-2002-2-page-91.htm. Accessed 12 February 2021.

Bolzman, Claudio. "Elementos para una aproximación teórica al exilio". Revista andaluza de antropología, no. 3, 2012, Migraciones en la globalización, http://asana -andalucia.org/revista/uploads/raa/n3/claudio.pdf. Accessed 12 February 2021.

Bradley, Megan. Truth-telling and displacement: Patterns and prospects. Advancing Transitional Justice Series. Washington, DC, Brookings-LSE Project on Internal Displacement, 2013, www.ictj.org/sites/default/files/ICTJ-Research-Brief-Displacem ent-Truth-Bradley.pdf. Accessed 19 July 2021.

Bradley, Megan and Roger Duthie. Doing justice for refugees and IDPs? Confronting displacement through transitional justice. Washington, DC, Brookings Institution, 2012, www.brookings.edu/opinions/doing-justice-for-refugees-and-idps-confronting-displace ment-through-transitional-justice. Accessed 14 December 2020.

Centro Nacional de Memoria Historica (CNMH). Exilio Colombiano. Huellas del conflicto armado más allá de las fronteras. Bogotá, CNMH, 2018, https://centrodem emoriahistorica.gov.co/exilio-colombiano-huellas-del-conflicto-armado-mas-alla-de -las-fronteras. Accessed 15 December 2020.

Cochrane, Feargal, Baser, Bahar, and Swain, Ashok. "Home Thoughts from Abroad: Diasporas and Peace-Building in Northern Ireland and Sri Lanka". Studies in Conflict \& Terrorism, vol. 32, no. 8, 2009, pp. 681-704,doi:10.1080/10576100903040716.

De Ryck, Paul, and Stéphanie Lopez Villamil. "Challenges to the governance of the return of victims abroad to Colombia". Oxford Monitor of Forced Migration, vol. 8, no. 2, 2020, pp. 88-102, www.researchgate.net/publication/338411822_Challenges_to_ 


\section{Stephan Parmentier, Mina Rauschenbach and Laura Hein}

the_Governance_of_the_Return_of_Victims_Abroad_to_Colombia/citations. Accessed 12 February 2021.

Díaz Pabón, Fabio Andrés, editor. "Transitional justice and the 'Colombian peace process"”. Truth, Justice and Reconciliation in Colombia. Transitioning from Violence, London, Routledge, 2018, doi:10.4324/9781315148373.

Dosdad, Ángela Iranzo, and Wooldy Edson Louidor. "Entre la guerra y la paz: los lugares de la diáspora colombiana”. Bogotá, Universidad de los Andes y Pontificia Universidad Javeriana, 2018, https://uniandes.edu.co/es/publicaciones/libro-entre-la -guerra-y-la-paz-los-lugares-de-la-diaspora-colombiana-angela-iranzo-dosdad-y-w ooldy-edson-louidor-edicion-academica-y-compilacion. Accessed 15 December 2020.

Estrada Rodriguez, Johanne Alexis, and Jorge Enrique Aponte Otalvaro. "Memories of political exile in the armed conflict in Colombia: contributions to the postagreement". Ciudad Paz-ando, vol. 11, no. 2, 2018, pp. 52-60, doi:10.14483/ $2422278 X .13086$.

Étiemble, Angélina. "Tamouls du Sri Lanka en France: Politisation de l'exil dans l'ombre des Tigres". Revue européenne des migrations internationales, vol. 33, no, 4, 2017, pp. 65-86, doi:10.4000/remi.9376.

Franco, Marina, and Carlos Pérez. "Between urgency and strategy: Argentine exiles in Paris, 1976-1983”. Latin American Perspectives, vol. 34, no. 4, 2007, pp. 50-67, doi:10.1177/0094582X07302906.

Gomez, Diana. "Les droits des victimes dans les accords de paix de la Havane". IdeAs, 2017, http://journals.openedition.org/ideas/1846. Accessed 15 December 2020, doi:10.4000/ideas.1846.

Haider, Huma. "Transnational transitional justice and reconciliation: The participation of conflict-generated diasporas in addressing the legacies of mass violence". Journal of Refugee Studies, vol. 27, no. 2, 2014, pp. 207-233, https://doi.org/10. 1093/jrs/feu002.

Halilovich, Hariz. "Reclaiming erased lives: Archives, records and memories in postwar Bosnia and the Bosnian diaspora”. Archival Science, 2014, pp. 231-247.

Hijas y Hijos del Exilio. Carta Abierta de Hijas y Hijos del Exilio. 2006, www.facebook. com/permalink.php?story_fbid=1582175202095712\&id=1582161152097117. Accessed 14 February 2021.

International Center for Transitional Justice, "Colombia's Truth Commission prepares to embark on the extra-territorial truth-telling process", www.ictj.org/news/ colombia $\% \mathrm{E} 2 \% 80 \% 99 \mathrm{~s}$-truth-commission-prepares-embark-extraterritorial-truth-t elling-process. Accessed 24 July 2021.

Jelin, Elisabeth. State Repression and the Labors of Memory. Minneapolis, University of Minnesota Press, 2003.

Jensen Silvina. "Memorias Lights, memorias anestesiadas. Reflexiones acerca de los olvidos del exilio en el relato público y social de los setenta en la Argentina". Los usos del olvido: recorridos, dimensiones y nuevas preguntas, edited by Patricia G. Flier, Rosario, Prohistoria Ediciones, 2014.

Jimeno, Eliana. "Historical memory as symbolic reparation". Truth, Justice and Reconciliation in Colombia: Transitioning from Violence, edited by Fabio Andrés Díaz Pabón, London, Routledge, 2018, pp. 136-153, doi:10.4324/9781315148373-9.

Karabegović, Dženeta. "Što Te Nema?: Transnational cultural production in the diaspora in response to the Srebrenica genocide". Nationalism and Ethnic Politics, vol. 20, no. 4, 2014, pp. 455-475, https://doi.org/10.1080/13537113.2014.969151. 
Karabegović, Dženeta. "Who chooses to remember? Diaspora participation in memorialization initiatives". Ethnic and Racial Studies, vol. 42, no. 11, 2019, pp. 19111929, doi:10.1080/01419870.2019.1577473.

Keck, Margaret E., and Kathryn Sikkink. Activists beyond borders: Advocacy networks in international politics. Ithaca, NY, Cornell University Press, 1998.

Koinova, Maria. "Critical junctures and transformative events in diaspora mobilisation for Kosovo and Palestinian statehood". Journal of Ethnic and Migration Studies, vol. 44, no. 8, 2018, pp. 1289-1308, doi:10.1080/1369183X.2017.1354158.

Koinova, Maria. "How refugee diasporas respond to trauma". Current History, vol. 115, 2016, pp. 322-324, doi:10.1525/curh.2016.115.784.322.

Koinova, Maria and Dzeneta Karabegovic. "Causal mechanisms in diaspora mobilizations to transitional justice". Ethnic and Racial Studies, vol. 42, no. 11, 2019, pp. 1809-1829, https://doi.org/10.1080/01419870.2019.1624802.

Lacroix, Thomas, and Elena Fiddian-Qasmiyeh. "Refugee and diaspora memories: The politics of remembering and forgetting". Journal of Intercultural Studies, vol. 34, no. 6, 2013, pp. 684-696, https://doi.org/10.1080/07256868.2013.846893.

Laing, Nyasha. Colombia's Truth Commission prepares to embark on the extraterritorial truth-telling process. 2018, www.ictj.org/news/colombia $\% \mathrm{E} 2 \% 80 \% 99$ s-truth-comm ission-prepares-embark-extraterritorial-truth-telling-process. Accessed 14 February 2021.

Lida, Clara Eugenia, Horacio Gutiérrez Crespo, and Pablo Yankelevich. Argentina, 1976: Estudios en torno al golpe de estado. México, El Colegio de México, 2007.

Lutz, Ellen, and Kathryn Sikkink. "The justice cascade: The evolution and impact of foreign human rights trials in Latin America". Chicago Journal of International Law, vol. 2, no. 1, art. 3, 2001, https://chicagounbound.uchicago.edu/cjil/vol2/iss1/ 3. Accessed 14 February 2021.

Martínez Leguízamo, Jeisson Oswaldo. "El exilio colombiano en España: Los diálogos de paz, un antes y un después". Estudios, vol. 38, 2017, pp. 105-121, https://dia Inet.unirioja.es/servlet/articulo?codigo=6237916. Accessed 15 February 2021.

McDowell, Christopher. "Les Tamouls en Suisse. L'émergence d'une communauté post-asilaire?”. Hommes \& Migrations, vol. 3, no. 1291, 2011, pp. 104-115, https:// doi.org/10.4000/hommesmigrations.685.

McEvoy, Kieran, and Lorna McGregor, editors. Transitional justice from below: Grassroots activism and the struggle for change. Oxford, Hart Publishing, 2008.

Orjuela, Camilla. "Distant warriors, distant peace workers? Multiple diaspora roles in Sri Lanka's violent conflict". Global Networks, vol. 8, no. 4, 2008, pp. 436-452, doi:10.1111/j.1471-0374.2008.00233.x.

Orjuela, Camilla. "Mobilising diasporas for justice: Opportunity structures and the presencing of a violent past". Journal of Ethnic and Migration Studies, vol. 44, no. 8, 2018, pp. 1357-1373, doi:10.1080/1369183X.2017.1354163.

Pagina 12. El exilio como otra violación a los derechos humanos de la dictadura. 2006, www.pagina12.com.ar/diario/elpais/1-68935-2006-06-24.html. Accessed 14 February 2021.

Rauschenbach, Mina, Stephan Parmentier, and Maarten Van Craen. "Towards social restoration in Bosnia and Herzegovina: Exploring the place of symbolic forms of transitional justice". Healing and Peacebuilding After War. Transforming Trauma in Bosnia and Herzegovina, edited by Julianne Funk, Nancy Good and Marie Berry, Studies in Peace and Conflict Resolution series, Abingdon, Routledge, 2020, pp. 167-188, https://doi.org/10.4324/9780429397745. 
Riaño Alcalá, Pilar, and Maria Victoria Uribe. "Constructing memory amidst war: The historical memory group of Colombia". International Journal of Transitional Justice, vol. 10, no. 1, 2016, pp. 6-24, https://doi.org/10.1093/ijtj/ijv036.

Roht-Arriaza, Naomi. The Pinochet effect: Transnational justice in the age of human rights. Philadelphia, University of Pennsylvania, 2005.

Schultz-Kraft, Markus. Colombia's quest for historic memory and peacebuilding. 2017, www.oxfordresearchgroup.org.uk/blog/colombias-quest-for-historic-memory-and-p eacebuilding. Accessed 14 December 2020.

Sikkink, Kathryn. "The Age of Accountability: The global rise of individual criminal accountability". Amnesty in the Age of Human Rights Accountability: Comparative and international perspectives, edited by Leigh Payne and Francesca Lessa, New York, Cambridge University Press, 2012, pp. 19-41.

Stokke, Esppen, and Eric Wiebelhaus-Brahm. "Syrian diaspora mobilization: Vertical coordination, patronage relations, and the challenges of fragmentation in the pursuit of transitional justice". Ethnic and Racial Studies, vol. 42, no. 11, 2019, pp. 1930-1949, https://doi.org/10.1080/01419870.2019.1572909.

Swisspeace. Participation of the diaspora in the Colombian Truth Commission. 2019, https://koff.swisspeace.ch/fileadmin/user_upload/JLPM_CaseStudyColombia.pdf. Accessed 15 December 2020.

Tamayo Gomez, Camilo. "Victims' collective memory and transitional justice in postconflict Colombia: The case of the March of Light". Memory Studies, 2019, pp. 114, https://doi.org/10.1177/1750698019882055.

Teodora, Anca-Teodora, and Serban-Oprescu Oprescu. "From exile to diaspora and from national to transnational binds under the driving forces of globalization." Journal of International Studies, vol. 6, no. 1, 2013, pp. 96-102, doi:10.14254/20718330.2013/6-1/9.

Van Hear, Nicholas, and Giulia Liberatore. "Shifting forms of diaspora engagement among the Sri Lankan Tamil diaspora”. Diasporas reimagined: Spaces, practices and belonging, edited by Nando Sigona, Alan Gamlen, Giulia Liberatore and Hélène Neveu Kringelbach, Oxford, Oxford Diasporas Programme, 2015, pp. 211-216.

Wiebelhaus-Brahm, Eric. "Exploring variation in diasporas' engagement with transitional justice processes". Journal of Peacebuilding \& Development, vol. 11, no. 3, 2016, pp. 23-36, https://doi.org/10.1080/15423166.2016.1226933.

Yankelevich, Pablo. "Exilio y dictadura," in Argentina, 1976: Estudios en torno al golpe de Estado, edited by Clara Lida, Crespo Horacio and Yankelevich Pablo, Mexico, El Colegio de México, 2017, pp. 205-231.

Young, Laura, and Rosalyn Park. "Engaging diasporas in truth commissions: Lessons from the Liberia Truth and Reconciliation Commission diaspora project". International Journal of Transitional Justice, vol. 3, no. 3, 2009, pp. 341-361, http s://doi.org/10.1093/ijtj/ijp021. 